\title{
Aromatherapy in the treatment of rosacea induced by Helicobacter pylori
}

\author{
DOI: https://doi.org/10.5114/pq.2019.84271
}

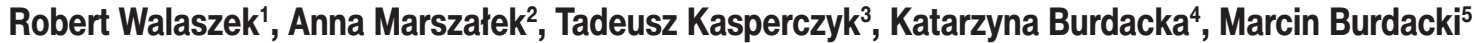 \\ ${ }^{1}$ Section of Biological Regeneration, University of Physical Education in Krakow, Krakow, Poland \\ ${ }^{2}$ Public Elementary School of Friends of Catholic Schools Association in Hucisko-Pewelka, Hucisko, Poland \\ ${ }^{3}$ Section of Professional Cosmetology, University of Physical Education in Krakow, Krakow, Poland \\ ${ }^{4}$ Department of Recreation Methodology, University of Physical Education in Krakow, Krakow, Poland \\ ${ }^{5}$ Institute of Physiotherapy, Faculty of Health Sciences, Jagiellonian University, Krakow, Poland
}

\section{Abstract}

Introduction. Recent study results show that essential oils obtained from some plants have a strong bactericidal effect against many pathogenic microorganisms and therefore they may play a supportive role in the prevention and treatment of infections caused by Helicobacter pylori. Infection with Helicobacter pylori is a suspected cause of rosacea, a chronic multi-phase inflammatory disease of the face, manifesting with vascular changes in the form of characteristic erythema. The purpose of this work was to present aromatherapy as a safe method supporting the treatment of rosacea induced by Helicobacter pylori.

Methods. The paper is a narrative review of the world scientific literature.

Results. Essential oils that exert an antimicrobial effect on Helicobacter pylori are presented. They penetrate the cell wall and cell membrane of the microorganisms, disturb the integrity of the structures, and lead to bacterial cell death.

Conclusions. The broad range of effects, rapidity of action, and efficacy of aromatherapy make it an effective weapon against Helicobacter pylori infections.

Key words: aromatherapy, essential oils, Helicobacter pylori, rosacea

\section{Introduction}

Rosacea is a chronic multi-phase inflammatory disease of the skin of face, frequently characterized by alternating periods of exacerbation and remission $[1,2]$. The main symptom of the condition is vascular changes in the form of erythema [3]. Along with disease progression, secondary eruptions begin to appear on the erythematous background, such as telangiectasias, papules and pustules, oedema, and sometimes also soft tissue hypertrophy [4]. According to statistical data, rosacea affects $1-10 \%$ of the population, mainly from the 30-55-year age group [5].

In spite of many research studies performed to date, the etiopathogenesis of rosacea remains unclear [1, 6]. According to Górkiewicz-Petkow [7], the multi-phase nature of the condition is related to the contribution of various factors and various pathogenetic mechanisms at particular stages of the disease. Many authors, on the basis of experimental studies, suggest that the most important mechanisms participating in the pathogenesis of rosacea are the following: disturbances of congenital immune response, vascular problems, and the effects of reactive oxygen species (ROS) and of protease enzymes [8-11]. Yamasaki and Gallo [12] underline that inflammatory process induced by Helicobacter pylori may be a cause of this disease, as well. This infection is found in $30-40 \%$ of the North American population, $60-80 \%$ of the Central European population, $30-40 \%$ of the Western European population, and as many as $90 \%$ of people from developing countries [13, 14]. The bacterium is currently considered to be the most important factor inducing chronic and acute inflammatory conditions of the stomach and its presence significantly increases the risk of gastric and duodenal peptic ulcers development [15-17]. Helicobacter pylori resistance to gastric acid is possible owing to the presence of a urease enzyme that catalyses the reactions of urea breakdown into ammonia and carbon dioxide, thus neutralising the effects of gastric acid [18].

The results of recent clinical studies have shown the presence of anti-Helicobacter pylori antibodies in the serum of patients with rosacea. The antibodies were detected in $80 \%$ of patients who additionally experienced dyspeptic symptoms [19-21]. Furthermore, strains of varying virulence level were isolated among these bacteria. In type I bacteria, including $60-80 \%$ of Helicobacter pylori strains, production of strongly immunogenic CagA protein of cytotoxic activity was observed. Besides, type I bacteria produce vacuolating cytotoxin VacA, whose secretion is synchronised with CagA translocation to gastric epidermal cells. In $67 \%$ of 60 rosacea patients with concomitant Helicobacter pylori infection, CagA (+) strain and elevated plasma levels of tumour necrosis factor $\alpha$ and interleukin 8 were present; in the control group, a CagA (+) strain was found in $32 \%$ of cases [21]. On the basis of these studies results, the virulent CagA (+) Helicobacter pylori strain was speculated to contribute to induction of rosacea symptoms through elevation of serum levels of some cytokines [19, 22].

Another conception concerning the pathogenicity of Helicobacter pylori assumes that the bacterium has the ability to increase the plasma levels of ROS and contributes to a release of proinflammatory cytokines in a mechanism dependent on TLR2 and TLR4 receptors activation in epithelial cells of the gastric mucosa [19, 23, 24]. Subsequently, ROS

Correspondence address: Robert Walaszek, University of Physical Education in Krakow, al. Jana Pawła II 78, 31-571 Krakow, Poland, e-mail: robert.walaszek@awf.krakow.pl

Received: 11.02 .2019

Accepted: 25.03 .2019

Citation: Walaszek R, Marszałek A, Kasperczyk T, Burdacka K, Burdacki M. Aromatherapy in the treatment of rosacea induced by Helicobacter pylori. Physiother Quart. 2019;27(2):17-21; doi: https://doi.org/10.5114/pq.2019.84271. 
may contribute to the development of skin problems in different ways, including, but not limited to, blocking tissue metalloproteinase inhibitors [25].

At present, various therapies are used in the treatment of Helicobacter pylori infection and some of them lead to the inhibition of bacterial growth or to the bacterium elimination $[26,27]$. A treatment combining three drugs (two antibiotics and an inhibitor of hydrochloric acid secretion in the stomach) provides highest efficacy, reaching $90 \%$. Adverse effects are relatively frequent during the treatment (15-30\% of cases) and include dysgeusia, nausea, vomiting, abdominal pains, and diarrhoea. The observation of growing resistance of the bacterium to the applied antibiotics and decrease of treatment efficacy leads to continuous search for natural therapeutic agents that inhibit the microorganism [28]. Studies conducted in the recent years have shown that some plant-derived products, with low toxicity and rare side effects, exert a strong bactericidal effect against many pathogenic microorganisms and may have a supportive role in the prevention and treatment of infections triggered by Helicobacter pylori.

The purpose of this work was to present aromatherapy as a method supporting the treatment of rosacea induced by Helicobacter pylori.

\section{Methods}

The paper is a narrative review based on the search of the world scientific literature. Because of the low number of publications found in databases (Web of Science, PubMed, Medline, EBSCO, Scopus, Google Scholar, CINAHL), the authors did not decide to perform a formal systematic review.

\section{Aromatherapy}

Aromatherapy consists in the use of natural essential oils obtained from plants with therapeutic properties for medical purposes [29, 30]. It belongs to natural medicine methods. Numerous benefits from its action on the human body make it more and more popular. The main forms of aromatherapy include massages, inhalations, and aromatherapeutic baths [31].
Essential oils are not chemically uniform; in the majority of cases, they constitute mixtures of many organic compounds. These may include terpene hydrocarbons and their oxygenated derivatives, alcohols, aldehydes, ketones, organic acids, esters, and ethers [32]. Essential oils may enter the body in two ways [29, 33]:

1. Via the respiratory system. Along with the inspired air, aromatic molecules enter the circulation and then they reach internal organs and brain. Aromatic substances are detected by olfactory receptors located in the olfactory epithelium of the nasal cavity and from this point information is transferred to the olfactory bulb and then to higher levels of the nervous system.

2. Via the skin. The small dimensions of the compounds of essential oils enable them to penetrate the skin, mainly through hair follicles and sebaceous and sweat glands.

\section{Ethical approval}

The conducted research is not related to either human or animal use.

\section{Results}

This paper presents a suggestion to use aromatherapy in the treatment of rosacea; therefore, the presented essential oils are limited to those that owing to their properties have an antimicrobial effect on Helicobacter pylori (Table 1). Being highly lipophilic, these compounds easily penetrate the cell wall and cell membrane of various microorganisms, disturbing the integrity of these structures and, finally, leading to death of bacterial cells [34, 35].

\section{Discussion}

Scientific reports inform that plant extracts containing several active secondary metabolites, including, but not limited to, flavonoids, tannins, glucosinolates, or terpene compounds, show strong bactericidal activity against many pathogenic microorganisms: among others, Helicobacter pylori. Six flavonoid compounds have been isolated from a chloroform extract of Cistus laurifolius leaves. Out of them, 3-methylquercetin ether - isorhamnetin - appears to have the stron-

Table 1. Essential oils with antimicrobial effect [36-41]

\begin{tabular}{|c|c|c|}
\hline English name & Latin name & Region of origin \\
\hline Laurel-leaf cistus & Cistus laurifolius & Mediterranean Basin \\
\hline Grapefruit & Citrus paradisi & Northern Africa, Europe, Asia \\
\hline Oregano & Origanum vulgare & Northern Africa, Europe \\
\hline Thyme & Thymus vulgaris & New South Wales \\
\hline Tea tree & Melaleuca alternifolia & Mediterranean countries \\
\hline Lemongrass & Cymbopogon citratus & Melanesia \\
\hline Ginger & Zingiber officinale & Central Asia \\
\hline Garlic & Allium sativum & Mediterranean region \\
\hline Lavender & Lavandula officinalis & Eurasia, Northern Africa \\
\hline Rosemary & Rosmarinus officinalis & South America \\
\hline Carnation & Dianthus & Southern Europe, Asia \\
\hline Lemon verbena & Aloysia citrodora & Melissa officinalis \\
\hline Lemon balm & &
\end{tabular}


gest activity against Helicobacter pylori, and quercetin 3,7-dimethyl ether and kaempferol 3,7-dimethyl ether exert the weakest effect [37]. Cavallito and Bailey [36], in turn, showed the influence of grapefruit extract flavonoids (hesperidin, poncirin, and naringin, among others) on Helicobacter pylori growth. O'Gara et al. [42] studied the effect of essential oil obtained from grapefruit tree on Helicobacter pylori. They observed that this oil, at a concentration of $1000 \mu \mathrm{g} / \mathrm{ml}$, had bactericidal effect on a strain of Helicobacter pylori after 1-hour incubation. They obtained a similar result with 10 -fold lower concentration $(100 \mu \mathrm{g} / \mathrm{ml})$ after 24-hour exposition. Minimal bactericidal concentrations for the 8 examined strains read after 24 hours ranged from 40 to $>100 \mu \mathrm{g} / \mathrm{ml}$.

Strong inhibition of Helicobacter pylori growth was revealed in screening tests of activity of essential oils obtained from a number of plants: wild carrot (Daucus carota), Ceylon cinnamon tree (Cinnamomum zeylanicum), winter savory (Satureja montana), true chamomile (Matricaria recutita), bitter orange (Citrus aurantium), spearmint (Mentha spicata), cloves (Eugenia caryophylata), field mint (Mentha arvensis), camphor catnip (Nepeta camphorata), lemon balm (Melissa officinalis), peppermint (Mentha piperita), common sage (Salvia officinalis), manuka myrtle (Leptospermum scoparium), true cardamom (Elettaria cardamomum), coriander (Coriandrum sativum), fennel (Foeniculum vulgare), meridian fennel (Carum carvi), basil (Ocimum basilicum), and star anise (Illicium verum) [43]. Studies of other authors confirmed the efficacy of essential oil plants, including popular spices, in fighting Helicobacter pylori [38]. Oregano oil and monolaurin (a substance obtained from coconut oil, containing monoglycerides and fatty acids) administered alone or in combination effectively inhibited Helicobacter pylori growth, which suggests that they may be useful in monotherapy or in combination with antibiotics [38]. Thyme water extracts have shown a strong inhibitory effect on Helicobacter pylori, as well [39]. Cermelli et al. [40], on the basis of their own studies, suggested that thyme extracts might be used for preparation of a therapeutic composition inhibiting the growth of the discussed bacterium and decreasing urease activity. Similar activity was also found for oils from many commonly known and used plants, e.g. from ginger rhizome and from lemon balm. Experiments performed by other authors confirmed antimicrobial activity of garlic oil, containing allicin as active substance [42]. Its high efficacy against Helicobacter pylori was also reported [44, 45]. Bacteriostatic effects of rosemary, lavender, and tea tree leaf oils have been proved, too. In in vitro studies, lemongrass oil and lemon verbena oil appeared to be the most effective ones. They inhibit Helicobacter pylori growth already at very low concentrations (at the level of $0.01 \%$ ). According to investigators, the substance responsible for the bactericidal effect on Helicobacter pylori is citral, the main component of these oils [41]. Inhibition of Helicobacter pylori growth was also shown when eugenol (main component of the clove oil) and cinnamon aldehyde (obtained from cinnamon bark) were used [46]. Numerous ongoing in vitro studies are promising and suggest a possibility to use these oils or some of their components in the treatment of Helicobacter pylori infections. Their enormous advantage is the fact that they remain active even in the strongly acidic environment of the stomach ( $\mathrm{pH} 4-5)$. Furthermore, no resistance development to the examined essential oils was found in this microorganism [47].

\section{Conclusions}

Owing to a wide range of various biological effects, aromatherapy may be a favourable alternative in the prevention and treatment of infections. Essential oils and their terpene components are proved to have antibacterial, antiviral, antifungal, antiparasitic, and anti-inflammatory effects [40, 48-50]. Despite the fact that numerous studies confirm the bactericidal impact of essential oils, they still remain in the shadow of pharmacological treatments and have only an adjunctive role. However, the broad range of effects, rapidity of action, and efficacy of aromatherapy make it an effective weapon against Helicobacter pylori infections. Therefore, aromatherapy should be popularised with all its positive effects, encouraging researchers to continue investigation of this field of natural medicine [51, 52]. Further experiments will certainly contribute to the discovery of new aspects of aromatherapy.

\section{Disclosure statement}

No author has any financial interest or received any financial benefit from this research.

\section{Conflict of interest}

The authors state no conflict of interest.

\section{References}

1. Wilkin J, Dahl M, Detmar M, Drake L, Feinstein A, Odom R, et al. Standard classification of rosacea: report of the National Rosacea Society Expert Committee on the Classification and Staging of Rosacea. J Am Acad Dermatol. 2002;46(4):584-587; doi: 10.1067/mjd.2002. 120625.

2. Erdogan HK, Bulur I, Kocaturk E, Saracoglu ZN, Alatas $\mathrm{O}$, Bilgin M. Advanced oxidation protein products and serum total oxidant/antioxidant status levels in rosacea. Adv Dermatol Allergol. 2018;35(3):304-308; doi: 10.5114/ada.2018.76228.

3. Powell FC. Rosacea. N Engl J Med. 2005;352(8):793803; doi: 10.1056/NEJMcp042829.

4. Crawford GH, Pelle MT, James WD. Rosacea: I. Etiology, pathogenesis, and subtype classification. J Am Acad Dermatol. 2004;51(3):327-341; doi: 10.1016/j.jaad.2004.03. 030.

5. Kyriakis KP, Palamaras I, Terzoudi S, Emmanuelides S, Michailides C, Pagana G. Epidemiologic aspects of rosacea. J Am Acad Dermatol. 2005;53(5):918-919; doi: 10.1016/j.jaad.2005.05.018.

6. Heymann WR. Rosacea subtype-directed therapy. J Am Acad Dermatol. 2004;51(1):90-92; doi: 10.1016/j.jaad. 2004.03.012.

7. Górkiewicz-Petkow A. Rosacea: etiopathogenesis and treatment [in Polish]. Przegl Dermatol. 2007;94(3):373-383.

8. Nally JB, Berson DS. Topical therapies for rosacea. J Drugs Dermatol. 2006;5(1):23-26.

9. Izikson L, English JC $3^{\text {rd }}$, Zirwas MJ. The flushing patient: differential diagnosis, workup, and treatment. J Am Acad Dermatol. 2006;55(2):193-208; doi: 10.1016/j.jaad.2005. 07.057.

10. Bakar O, Demirçay Z, Yuksel M, Haklar G, Sanisoglu Y. The effect of azithromycin on reactive oxygen species in rosacea. Clin Exp Dermatol. 2007;32(2):197-200; doi: 10.1111/j.1365-2230.2006.02322.x.

11. Yang CS, Shin DM, Lee HM, Son JW, Lee SJ, Akira S, et al. ASK1-p38 MAPK-p47phox activation is essential for inflammatory responses during tuberculosis via TLR2- 
ROS signalling. Cell Microbiol. 2008;10(3):741-754; doi: 10.1111/j.1462-5822.2007.01081.x.

12. Yamasaki K, Gallo RL. The molecular pathology of rosacea. J Dermatol Sci. 2009;55(2):77-81; doi: 10.1016/j. jdermsci.2009.04.007.

13. Peterson WL, Fendrick AM, Cave DR, Peura DA, Garabedian-Ruffalo SM, Laine L. Helicobacter pylori-related disease: guidelines for testing and treatment. Arch Intern Med. 2000;160(9):1285-1291; doi: 10.1001/ archinte.160.9.1285.

14. Yilmaz B, Koseoglu H, Coskun Y, Deveci M, Kekilli M. Comparison between different first-line therapy protocols in eradicating Helicobacter pylori in a region with high clarithromycin resistance. Gastroenterology Rev. 2018;13(2):150-156; doi: 10.5114/pg.2018.72732.

15. Jagusztyn-Krynicka EK, Godlewska R, Łaniewski P. Helicobacter pylori - pathogen of the year 2005 [in Polish]. Kosmos. 2005;54(4):307-319.

16. Konrad P, Chojnacki J, Gąsiorowska A, Rudnicki C, Kaczka A, Chojnacki C. Therapeutic efficacy of amoxicillin and rifaximin in patients with small intestinal bacterial overgrowth and Helicobacter pylori infection. Gastroenterology Rev. 2018;13(3):213-217; doi: 10.5114/pg.2018. 74228.

17. Zakrzewski M, Maciorkowska M, Gładka A, RoszkoKirpsza I, Czarniecka-Barglowska K, Maciorkowska E. Cutaneous manifestation of Helicobacter pylori infection. Pediatr Pol. 2018;93(5):403-408; doi: 10.5114/ polp.2018.80024.

18. Kusters JG, van Vliet AH, Kuipers EJ. Pathogenesis of Helicobacter pylori infection. Clin Microbiol Rev. 2006; 19(3):449-490; doi: 10.1128/CMR.00054-05.

19. Baz K, Cimen MY, Kokturk A, Aslan G, Ikizoglu G, Demirseren DD, et al. Plasma reactive oxygen species activity and antioxidant potential levels in rosacea patients: correlation with seropositivity to Helicobacter pylori. Int J Dermatol. 2004;43(7):494-497; doi: 10.1111/j.13654632.2004.02137.x.

20. Yamasaki K, Schauber J, Coda A, Lin H, Dorschner RA, Schechter NM, et al. Kallikrein-mediated proteolysis regulates the antimicrobial effects of cathelicidins in skin. FASEB J. 2006;20(12):2068-2080; doi: 10.1096/fj.06$6075 \mathrm{com}$.

21. Lazaridou E, Giannopoulou C, Fotiadou C, Vakirlis E, Trigoni A, loannides $D$. The potential role of microorganisms in the development of rosacea. J Dtsch Dermatol Ges. 2011;9(1):21-25; doi: 10.1111/j.1610-0387.2010. 07513.x.

22. Szlachcic A, Śliwowski Z, Karczewska E, Bielański W, Pytko-Polonczyk J, Konturek SJ. Helicobacter pylori and its eradication in rosacea. J Physiol Pharmacol. 1999; 50(5):777-786.

23. Kawahara T, Kuwano Y, Teshima-Kondo S, Kawai T, Nikawa T, Kishi K, et al. Toll-like receptor 4 regulates gastric pit cell responses to Helicobacter pylori infection. J Med Invest. 2001;48(3-4):190-197.

24. Smith MF Jr, Mitchell A, Li G, Ding S, Fitzmaurice AM, Ryan K, et al. Toll-like receptor (TLR) 2 and TLR5, but not TLR4, are required for Helicobacter pylori-induced NFkappa $\mathrm{B}$ activation and chemokine expression by epithelial cells. J Biol Chem. 2003;278(35):32552-32560; doi: 10.1074/jbc.M305536200.

25. Vincent C, Eris I. Metalloproteinase inhibitors in rosacea [in Polish]. Dermatol Estet. 2004;1(30):25-28.

26. Szadkowski A, Zemlak M, Muszyński J. Effectiveness of Helicobacter pylori eradication established on the basis of examination of antibiotic resistance of the bacteria. Gastroenterology Rev. 2018;13(2):93-98; doi: 10.5114/ pg.2018.75821.

27. Akpinar MY, Aksoy EK, Sapmaz F, Goktas Z, Uzman M, Nazligul Y. Comparison of moxifloxacin-based therapies and standard bismuth-based quadruple therapy for first-line treatment of Helicobacter pylori infection. Arch Med Sci Civil Dis. 2018;3:e81-e86; doi: 10.5114/ amscd.2018.78766.

28. Deroń E, Kieć-Świerczyńska M. The role of Helicobacter pylori in the development of skin diseases [in Polish]. Med Pr. 2002;53(4):333-337.

29. Nawrocka A, Ślężyńska M. Use of aromatherapy in relaxation [in Polish]. Refleksoterapia. 2010;2:14-18.

30. Kiełtyka-Dadasiewicz A, Gorzel M. Alternative therapies. Aromatherapy - raw materials and treatments [in Polish]. Eur J Med Technol. 2014;1(2):72-79.

31. Miosga L. Help me to be. Communication and sense stimulation in people with significant and deep mental retardation [in Polish]. Kraków: Impuls; 2006.

32. Feliczak-Guzik A, Jagodzińska K, Nowak I. Technology of manufacturing perfumes and essentials oils [in Polish]. Kostrzyń: Cursiva; 2013.

33. Hongratanaworakit T. Physiological effects in aromatherapy. Songklanakarin J Sci Technol. 2004;26(1):117-125.

34. Oussalah M, Caillet S, Lacroix M. Mechanism of action of Spanish oregano, Chinese cinnamon, and savory essential oils against cell membranes and walls of Escherichia coli 0157:H7 and Listeria monocytogenes. J Food Prot. 2006;69(5):1046-1055; doi: 10.4315/0362-028X69.5.1046.

35. Ultee A, Bennik MH, Moezelaar R. The phenolic hydroxyl group of carvacrol is essential for action against the foodborne pathogen Bacillus cereus. Appl Environ Microbiol. 2002;68(4):1561-1568; doi: 10.1128/AEM.68.4.15611568.2002.

36. Cavallito CJ, Bailey JH. Allicin, the antibacterial principle of Allium sativum. I. Isolation, physical properties and antibacterial action. J Am Chem Soc. 1944;66(11):19501951; doi: 10.1021/ja01239a048.

37. Ustün O, Ozçelik B, Akyön Y, Abbasoglu U, Yesilada E. Flavonoids with anti-Helicobacter pylori activity from Cistus laurifolius leaves. J Ethnopharmacol. 2006;108(3): 457-461; doi: 10.1016/j.jep.2006.06.001.

38. Preuss HG, Echard B, Enig M, Brook I, Elliott TB. Minimum inhibitory concentrations of herbal essential oils and monolaurin for Gram-positive and Gram-negative bacteria. Mol Cell Biochem. 2005;272(1-2):29-34; doi: 10.1007/s11010-005-6604-1.

39. Karimi Zarchil MA, Babaei A. An investigation of thyme effect on Helicobacter pylori. Middle East J Sci Res. 2006; 1(1):54-57.

40. Cermelli C, Fabio A, Fabio G, Quaglio P. Effect of eucalyptus essential oil on respiratory bacteria and viruses. Curr Microbiol. 2008;56(1):89-92; doi: 10.1007/s00284007-9045-0.

41. Chao LK, Hua KF, Hsu HY, Cheng SS, Liu JY, Chang ST. Study on the antiinflammatory activity of essential oil from leaves of Cinnamomum osmophloeum. J Agric Food Chem. 2005;53(18):7274-7278; doi: 10.1021/jf051151u.

42. O'Gara EA, Hill DJ, Maslin DJ. Activities of garlic oil, garlic powder, and their diallyl constituents against Helicobacter pylori. Appl Environ Microbiol. 2000;66(5):22692273; doi: 10.1128/aem.66.5.2269-2273.2000.

43. Reichling J, Schnitzler P, Suschke U, Saller R. Essential oils of aromatic plants with antibacterial, antifungal, an- 
tiviral, and cytotoxic properties - an overview. Forsch Komplementmed. 2009;16(2):79-90; doi: 10.1159/000 207196.

44. limuro M, Shibata H, Kawamori T, Matsumoto T, Arakawa T, Sugimura T, et al. Suppressive effects of garlic extract on Helicobacter pylori-induced gastritis in Mongolian gerbils. Cancer Lett. 2002;187(1-2):61-68; doi: 10.1016/S0304-3835(02)00401-9.

45. Sivam GP. Protection against Helicobacter pylori and other bacterial infections by garlic. J Nutr. 2001;131(3s): 1106S-1108S; doi: 10.1093/jn/131.3.1106S.

46. De Carvalho CC, da Fonseca MM. Carvone: why and how should one bother to produce this terpene. Food Chem. 2006;95(3):413-422; doi: 10.1016/j.foodchem. 2005.01.003.

47. Angioni, A, Barra A, Coroneo V, Dessi S, Cabras P. Chemical composition, seasonal variability, and antifungal activity of Lavandula stoechas L. ssp. stoechas essential oils from stem/leaves and flowers. J Agric Food Chem. 2006;54(12):4364-4370; doi: 10.1021/jf0603329.

48. Hammer KA, Carson CF, Riley TV. Antifungal activity of the components of Melaleuca alternifolia (tea tree) oil. J Appl Microbiol. 2003;95(4):853-860; doi: 10.1046/j.1365-2672. 2003.02059.x.

49. Kawata J, Kameda M, Miyazawa M. Cyclooxygenase-2 inhibitory effects and composition of the volatile oil from the dried roots of Lithospermum erythrorhizon. J Nat Med. 2008;62(2):239-243; doi: 10.1007/s11418-007-0221-0.

50. Baylac S, Racine P. Inhibition of 5-lipoxygenase by essential oils and other natural fragrant extracts. Int J Aromather. 2003;13(2-3):138-142; doi: 10.1016/S09624562(03)00083-3

51. Kasperczyk T, Mucha D, Walaszek R. Diagnostic methods in reflexology [in Polish]. Pol J Manual Med. 2015;19(1): 11-21.

52. Kasperczyk T, Momola I, Walaszek R. Selected methods of natural medicine at physiotherapy services [in Polish]. Pol J Manual Med. 2006;10(1):27-34. 